cumstances. In this case, the court did not accept the Director's decision, but it did not criticize his failure to act.

In Clatterbuck v. United States 32 the judicial attitude toward the prison authorities was more disapproving. After asserting that the legislation on mental defectives had not been working as expected, Judge Washington commented: "This court has on an earlier occasion in Clatterbuck's history, as Judge Bazelon points out, called the attention of the authorities to the provisions of section 4241. It may not be out of order to remind them of it once again." 33 Since the section 4245 examination is directly related to the work of the courts, it can be argued that it is proper for courts to order such an examination. However, judicial comment concerning the failure to hold a 4241 examination seems much less desirable.

It seems clear, from the words of the section and from the legislative history, that section 4245 was not intended to apply to prisoners actively seeking relief. However, the courts which have assumed the broader application have a basis for this assumption. It seems sensible that the prison board should communicate its findings and recommendations to the courts in any case where these findings are relevant to the determination of past competence to stand trial. It should make no difference that, in some cases, the prisoner is initiating the section 4245 proceeding. However, legislative change is necessary for a clear statement of the procedure to be followed by the prisoner. Any suggestions for legislative change must take into account an important distinction between section 4241 and section 4245 . Section 4241 has primarily a medical purpose of providing proper care for mentally ill prisoners; the section 4245 procedure leads to a legal conclusion concerning competency to stand trial. Any new channels of communication must include safeguards so that the medical emphasis in the examination and report will not distort the legal conclusion. ${ }^{34}$

32266 F.2d 893 (D.C. Cir. 1958).

33 Id. at 900 .

34 See, e.g., note 31 supra.

\title{
CONTROL OF THE UNAUTHORIZED PRACTICE OF LAW: SCOPE OF INHERENT JUDICIAL POWER
}

Many state supreme courts, relying upon the separation of powers clause of the state constitution, have asserted a broad power to regulate the practice of law. ${ }^{1}$ Some courts have claimed that the power is exclusive and that,

1 The Supreme Court of Oklahoma in In re Bledsoe, 186 Okla. 264, 97 P.2d 556, 557 (1939), explicitly acknowledged that the source of judicial power in this area was the general separation of powers clause. "There is no provision of the Constitution which specifically fixes the authority for determining the qualifications for admission to the bar in either the legislative or the judicial branch of government. The only applicable 
therefore, any legislation concerning the practice of law is invalid unless it is "in aid of the judiciary."2 The result is a judicial limitation on legislative power to regulate a wide range of activities which the courts may label the "practice of law." In short, these courts have decided that, in regulating these activities, the judiciary is the dominant branch of government. This comment will suggest that some state courts have asserted this dominant power over too great a range of persons and activities, and that the courts should restrict their claim of dominant power to the regulation of activities which directly affect the dignity and effective operation of the judicial process. Beyond this area of protecting the judicial process, the legislature should not be restricted in protecting the public through the exercise of its traditional police power. This does not mean that the courts should not initiate controls when the sole need is the protection of the public. If, however, the legislature has acted in the area of its dominant power, the courts should submit to the legislative policy determination rather than assert that such legislation not in aid of the judiciary is invalid. Some courts have failed to distinguish the area of dominant judicial power from the area in which their policy determination must be subordinate to the dominant legislative power.

The failure to distinguish the two types of judicial power has resulted in a judicial restriction upon legislative authorization of practice before state administrative agencies. A 1959 West Virginia case ${ }^{3}$ illustrates this judicial attitude. The state bar association sought to enjoin a union business agent from representing union members before the State Compensation Commissioner ${ }^{4}$ and preparing notices of appeal to the Workmen's Compensation Appeal Board. 5 The defendant contended that his practice was authorized

provision of the Constitution is section 1, art. 4, which is as follows: 'The powers of the government of the State of Oklahoma shall be divided into three separate departments: The Legislative, Executive, and Judicial; and except as provided in this Constitution, the Legislative, Executive and Judicial Departments of government shall be separate and distinct, and neither shall exercise the powers properly belonging to either of the others." " See also Bump v. District Court, 232 Iowa 623, 628, 5 N.W.2d 914, 917 (1914); People ex rel. Illinois State Bar Ass'n v. Peoples Stock Yard State Bank, 344 IIl. 462, 470, 176 N.E. 901,907 (1931). Other constitutions make specific allocations of power to regulate the practice of law. ARK. CONST. amend. 28 ("The Supreme Court shall make rules regulating the practice of law and the professional conduct of attorneys at law."); PHILIPPINE CONST. art. $8, \S 13$ (supreme court has power to promulgate rules subject to repeal, alteration or supplementation by the legislature).

2 E.g., In re Baker, 8 N.J. 324, 336, 85 A.2d 505, 512 (1951); cases cited in Dowling, The Inherent Power of the Judiciary, 21 A.B.A.J. 635, 638 n.33 (1935).

3 West Virginia State Bar v. Earley, 109 S.E.2d 420 (W.Va. 1959).

${ }^{4}$ The Brotherhood of Railroad Trainmen provides a service-a legal aid program-more directly related to the judicial process than that offered by the defendant in Earley. This service, too, has been attacked in the courts and has generally been disapproved. E.g., In re Brotherhood of Railroad Trainmen, 13 IIl. 2d 391, 150 N.E.2d 163 (1958), discussed in 20 U. PITT. L. REV. 85 (1958).

s In Goodman v. Beall, 130 Ohio 427, 200 N.E. 470 (1936), the Supreme Court of Ohio distinguished the original claim procedure from the rehearing proceedings before the 
by legislation which empowered the Commissioner to adopt rules of procedure. 6 Pursuant to this authorization the Commissioner had issued a rule which authorized a claimant or an employer to appear at proceedings before the Commissioner in person or by agent or attorney. The defendant contended that he had the right to appear as such agent for claimants and that the judiciary did not have an exclusive, inherent power to define the practice of law. The court rejected this contention:

The judicial department as one of the three separate and independent branches of the government of the state, has the inherent power to define, supervise, regulate and control the practice of law and the Legislature can not restrict or impair this power of the courts or permit or authorize laymen to engage in the practice of law.7

In the exercise of its inherent power, the West Virginia court held that the Commissioner could not authorize any lay practice which came within the court's definition of the "practice of law."

The dominant judicial power to regulate the practice of law has been asserted as a limitation on legislative power because it developed from the well-established power of courts to regulate admission to the bar. ${ }^{8}$ Legislatures have not been permitted to decide who must be admitted to the bar; they may establish only minimal qualifications. 9 The courts have long held that this limitation on legislative power is necessary because members of the bar fulfill a special role as "officers of the court." By regulating the admission of these "officers" the courts are able to protect the dignity and effective

Industrial Commission. The court accepted the legislative requirement that the claim proceeding must be simple without the "vexatious and protracted litigation which had proved so costly, exhaustive, and unsatisfactory, oft-times resulting in great injustice." 130 Ohio at 429,200 N.E. at 471 . However, the court held that the "preparation of a rehearing record should be in complete charge of an attorney at law." 130 Ohio at 433, 200 N.E. at 473. The West Virginia court did not consider this distinction in Earley.

6 W. VA. CODE ch. 23, $\$ 2506$ (1955). The case could have been decided on the narrow ground of statutory interpretation, as was recognized near the end of the opinion: "[The legislature did not] undertake to authorize... [the commissioner] to promulgate a rule by which a layman may appear as an agent in behalf of a claimant or employer in hearings before the commissioner and by permission of the commissioner practice before him. But even if the statute attempted to authorize the commissioner to promulgate a rule of that character such provison of the statute would be void as a legislative encroachment upon the inherent power of the judicial department of the government." West Virginia State Bar v. Earley, 109 S.E.2d 420, 439 (W.Va. 1959). It has been suggested that statutes delegating rule-making power to agencies should be construed narrowly. Bennett, NonLawyers and the Practice of Law Before State and Federal Agencies, 46 A.B.A.J. 705, 707 (1960).

7 West Virginia State Bar v. Earley, supra note 6, at 436.

8 For an early commentary on the power to regulate admission, see Lee, The Constitutional Power of the Courts Over Admission to the Bar, 13 HARv. L. REv. 233 (1899). This article discusses In re Day, 181 Ill. 73, 54 N.E. 646 (1899), in which the history of admission to the bar is outlined.

${ }^{9}$ See Application of Kaufman, 69 Idaho 297, 315, 206 P.2d 528, 539 (1949). See Dowling, supra note 2, at 638 . 
operation of the judicial process. The power to discipline and disbar members of the bar is considered inherently judicial by the same reasoning as that applied to the power to regulate admission.10 The power to discipline is closely related to the general contempt power by which a court may punish anyone who interferes with the orderly administration of justice by that court.11 The power to punish members of the bar, however, is not limited to activities which are directly related to matters before the court. The courts have assumed responsibility for maintaining high standards of character and competence among members of the bar. Legislation is generally held invalid if it limits the courts in the exercise of this inherent power.12 The courts may properly consider their power dominant whenever their primary concern is the protection of the dignity of the judicial process. This is the basis of the power to regulate admission and to discipline members of the bar. It is not, however, a proper basis for the regulation of all activities which the courts choose to label the "practice of law."

Some state courts have decided that the inherent power to regulate the practice of law necessarily makes them dominant beyond the limited area of maintaining the professional standards of the bar. They have asserted that the power to regulate members of the bar would be severely limited in practical effect if laymen were permitted to practice with impunity. 13 Thus the power

10 See, e.g., In re Bailey, 30 Ariz. 407, 413, 248 Pac. 29, 30-31 (1926): "Such being the law in regard to admission to the bar, it equally and necessarily follows that, whenever a practitioner by his conduct shows that he no longer possesses the qualifications required for his admission, he may be deprived of the privilege theretofore granted him, and such deprivation may be either under the authority of a statute prescribing the cause therefor, and the manner of procedure, or the court of its own inherent power may act. Following the principle applying in the case of admission to practice, the court will disbar an attorney for any reason and in any manner prescribed by the legislature. But a statute cannot limit the inherent power of the court which admitted him to also disbar him for any additional reason which may satisfy the court he is no longer fit to be one of its officers."

11 See, e.g., In re Baker, 8 N.J. 321, 335-36, 85 A.2d 505, 511-12 (1951). A dissent in this case called for restraint in the exercise of the inherent power since criminal contempt is a summary proceeding which operates in derogation of human liberties. Id. at 341 , $85 \mathrm{~A} .2 \mathrm{~d}$ at 515 . A note on this case suggests that legislative specificity should be substituted for the relative unpredictability of ad hoc judicial definition. 52 CoLuM. L. Rev. 429 (1952). Legislative limitations on the courts' contempt power have been recognized by some state courts. See Murphy v. Townley, 67 N.D. 560, 274 N.W. 857 (1937); State ex rel. Indianapolis Bar Ass'n v. Fletcher Trust Co., 211 Ind. 27, 5 N.E.2d 538 (1937). The technical ground of the decision in the latter case was the right of the defendant to purge his contempt. The history and justification of this rule are discussed in 5 Duke B.A.J. 106 (1937).

12 See In re Baker, supra note 11.

13 "It is generally conceded throughout the country that the power to control admissions to the bar and to discipline members of the bar is inherent in the judiciary. ... But whether inherent or express, these powers over the admission and discipline of members of the bar would be meaningless and futile if laymen might practice law with impunity.... The power to control admissions and to discipline the members of the bar necessarily carries with it the power to prevent laymen from practicing law." Vanderbilt, C.J., in In re Baker, 8 N.J. 321, 334, 85 A.2d 505, 511-12 (1951).

"Since an attorney is an officer of the court, the latter possesses the inherent power to 
to require that members of the bar meet certain standards has evolved into the power to determine what activities must be reserved exclusively for members of the bar. This judicial power is generalized as a power to regulate the "practice of law." In many cases, the courts consider primarily the protection of the public rather than the dignity of the judicial process in determining whether a particular activity is the "practice of law" and should be limited to members of the bar. That is, the courts ask whether the activity, if undertaken by laymen, will harm the public. ${ }^{14}$ If so, it is included within their definition of the "practice of law." This manner of defining the "practice of law" leads to the determination of the scope of an exclusive judicial power on the basis of the protection of the public rather than the protection of the judicial process. Of course, the proper boundary of dominant judicial power is not easy to determine. The protection of the judicial process is important only insofar as it results in the protection of the public. However, in asserting their duty to protect the public from lay practice before administrative agencies, the courts should recognize that they are acting in an area in which the legislative policy determination should be dominant.

There is little doubt that there is some inherent judicial power which should prevail over legislative power in order to assure the existence of the judiciary as a constitutionally independent branch of government.15 It is not the purpose of this comment to determine the exact boundary of that power; however, it is possible to illustrate that the power which has been claimed over unauthorized practice extends well beyond this boundary.

First, such a broad judicial power has not been recognized in all of the

supervise his conduct, both in and out of court, to the point of reprimanding or even removing him from office for misconduct.... It logically follows that the courts have the inherent power, apart from statute, to inquire into the conduct of any person-whether an individual, a lay agency, or a corporation-to determine whether he or it is usurping the functions of an officer of the court and illegally engaging in the practice of law and to put an end to such unauthorized practice where found to exist." Richmond Ass'n of Credit Men v. Bar Ass'n, 167 Va. 327, 335-36, 189 S.E. 153, 157 (1937).

14 "The justification for excluding from the practice of law persons who are not admitted to the bar and for limiting and restricting such practice to licensed members of the legal profession is not the protection of the members of the bar from competition or the creation of a monopoly for the members of the legal profession, but is instead the protection of the public from being advised and represented in legal matters by unqualified and undisciplined persons over whom the judicial department of the government could exercise slight or no control." West Virginia State Bar v. Earley, 109 S.E.2d 420, 435 (W. Va. 1959).

15 See, e.g., Bennett, supra note 6, at 706. Cf. Levin \& Amsterdam, Legislative Control over Judicial Rule-Making: A Problem in Constitutional Revision, 107 U. PA. L. REV. 1, 33 (1958): "We recognize that the outer boundaries of this sphere of total judicial autonomy have been difficult to locate with precision. Suffice that such a place of sanctuary exists and that whenever courts have felt themselves too tightly pressed by legislative regulation they have found in the doctrine of judicial independence a large reservoir of integral supremacy." 
states. 16 Judicial branches without this power have continued to exist and function effectively. Also, at the federal level, the United States Supreme Court has not claimed an equivalent power. ${ }^{17}$ Finally, the current legislativejudicial balance in the area of practice, procedure and administration in the courts suggests that the dominant judicial power that has been asserted over the practice of law is too broad:

For decades, if not for centuries, control over practice and procedure has been the subject of concurrent jurisdiction. There were the courts with an alleged inherent power to engage in rule-making, and there were the legislatures which in fact exercised and were, with but rare dissent, conceded ultimate authority over virtually the entire procedural area.18

It seems clear that the power to establish rules of practice and procedure is more closely related to the judicial process than the power over the "practice of law" as broadly defined. If the test for a dominant judicial power is its relation to the judicial process, the assertion of a dominant judicial power over all practice of law would seem inconsistent with the recognition of a dominant legislative power over rule-making. 19

16 In re Bercu, 69 N.Y.S.2d 730, 734 (1947), rev'd on other grounds, 273 App. Div. 524, 78 N.Y.S.2d 209 (1948), aff'd mem., 299 N.Y. 728, 87 N.E.2d 451 (1949); Matter of Cooper, 22 N.Y. 67 (1860); In re Applicants for License, 143 N.C. 1 (1906); In re Collins, 147 Cal. 8, 81 Pac. 220 (1905). But see Howe v. State Bar, 212 Cal. 222, 230, 298 Pac. 25, 28 (1931); In re McCowan, 177 Cal. 93, 104, 170 Pac. 1100, 1104 (1917).

17 Statement of Walter Gellhorn, in Cincinnati Conference on Law and Lawyers in the Modern World, 15 U. CINC. L. REv. 196, 197-98 (1941). In discussing admission to practice before federal administrative agencies, Professor Gellhorn commented: "Eradication of whatever defects there may be in prevailing controls over practice before federal agencies is peculiarly a matter within the competence of the national legislature and of the administrative bodies themselves. The Supreme Court has never expressed the belief, apparently held by some state courts, that prescribing qualifications for administrative practice is an inherent judicial power. On the contrary, in Goldsmith v. United States Board of Tax Appeals [270 U.S. 117 (1926)], the court held that an administrative tribunal, even in the absence of explicit statutory authorization to do so, may properly establish standards of admission to practice before it. Needless to add, Congress may itself do directly what, as the Supreme Court has said, it has impliedly permitted the agencies to do.

"It is possible, therefore, to discuss the problem of the federal administrative bar not in terms of constitutional powers or legalisms, but purely in terms of public interest." Id. at $197-98$.

18 Levin \& Amsterdam, supra note 15, at 3.

19 A possible explanation for this inconsistency can be found in the divergent historical development of the respective powers. In the unauthorized practice area, courts have assumed a major portion of the power and direct legislative attempts to encroach upon this power have been rare and unsuccessful. See discussion of the experience in Texas in notes $41 \& 42$ infra and text accompanying. If there is to be a change in this area, its direction must be toward greater legislative power. The history of allocation of power in the area of judicial rule-making is far different. In the formative years of American law, the courts lacked flexibility in establishing rules of procedure and the pressure for change was answered by legislative action. See Hyde, From Common Law Rules to Rules of Court, 22 WASH. U.L.Q. 187, 203 (1937). When this legislation resulted in a new solidification (see id. at 204), the pressure for change was exerted by seeking legislative enabling acts (Levin \& Amsterdam, supra note 15, at 4) rather than by asserting that the judicial branch was constitutionally authorized to wield the dominant power. 
There are varying degrees of legislative-judicial conflict in the area of unauthorized practice. State legislatures have not asserted their dominant authority as directly as they might have. The indirect nature of the legislative statement of policy may have contributed to the judiciary's failure to recognize the dominant legislative power. The policy statement is most direct if the legislature authorizes the practice explicitly in the statute. For example, legislatures have attempted to fix sufficient conditions for admission to the bar. ${ }^{20}$ Also, several workmen's compensation statutes provide that a party may be represented by his attorney or other agent.21 This is direct statutory authorization for the agency to establish requirements as it chooses for its own "bar." Authorization is less direct when an agency is granted a general power to establish rules of procedure. One of these rules might authorize lay representation. 22 A more explicit but less direct legislative statement of policy is involved if the statute authorizes practice through an exception to a prohibition. ${ }^{23}$ That is, the statute proscribing unauthorized practice in general may contain a section exempting certain groups or activities from the operation of the statute. There is no direct authorization, but in fact there is usually clear legislative intent to authorize. If the persons and activities apparently authorized are within the area of dominant legislative power, the courts should submit to the legislative declaration of policy. There is, of course, an interpretive problem with regard to legislative intent. It may well be that in exempting a particular group from the operation of a penal provision the legislature nevertheless intended to leave the courts free to prohibit certain practices by members of the exempted group. 24 The assertion of a judicial power of control in such a case would present no challenge to the theory of dominant legislative power.

${ }^{20}$ E.g., Idaho Sess. Laws 1949, ch. 73, $\S 1$, at 126, held unconstitutional in Application of Kaufman, 69 Idaho 297, 206 P.2d 528 (1949).

21 Colo. Rev. Stat. \$ 81-14-3 (1953); Conn. Gen. Stat. \$31-174 (1958); Wis. Stat. ANN. $\$ 102.17$ (1957). For a judicial interpretation of the phrase "agent or attorney" see State ex rel. Hunter v. Kirk, 133 Neb. 625, 629, 276 N.W. 380, 383 (1937). 1959).

22 See, e.g., the rule involved in West Va. State Bar v. Earley, 109 So. 2d 420 (W. Va.

${ }^{23}$ See, e.g., ILL. Rev. STAT. ch. 32, $\$ 415$ (1959), interpreted in People ex rel. Chicago Bar Ass'n v. Motorists Ass'n, 354 III. 595, 188 N.E. 827 (1933).

24 For example, a Texas statute created criminal penalties for the practice of law by anyone other than a member of the bar. Tex. Acts 1933,ch. 238, at835. The statute contained a detailed definition of the "practice of law" but provided that nothing contained therein was to prevent notaries public from drawing conveyances. A declaratory judgment was sought in the Texas courts as to the legality of the drafting of legal documents by a notary in connection with his business as an abstracter. The Court of Civil Appeals of Texas declared that because of the inherent power of the judiciary, the courts were free to rule on the legality of these practices in spite of the legislative proviso. Grievance Comm. v. Dean, 190 S.W.2d 126 (Tex. Civ. App. 1945). The same result might have been obtained had the court admitted the dominance of legislative power over judicial power in this area but interpreted the statute as a legislative delegation to the judiciary of responsibility for regulating the practices of notaries. 
Although state legislatures have not always implemented their policy determinations in the most direct manner possible, state courts have occasionally submitted to the legislative policy to some extent. In Cowern v. Nelson ${ }^{25}$ the Minnesota Supreme Court refused to relinquish any inherent power but did accept the legislative declaration of policy. The policy was stated as an exception of certain activities of real estate brokers from the general prohibitions of the unauthorized practice statute. The court accepted the defendant's contention that:

As a matter of comity rather than an acknowledgement of power the judicial branch should defer to the legislative regulation as a declaration of public policy in harmony with the expression of the courts in general, and a legislative effort to cooperate with and implement the efforts of the courts in the enforcement of that policy. 26

The Minnesota court left no doubt that it viewed itself as dominant over the legislative branch in regulating real estate brokers who draft legal instruments. However, the legislative policy was given some weight in the judicial determination of what was necessary to protect the public.

Other courts have exercised greater restraint in asserting the inherent judicial power. In Washington State Bar Ass'n v. Washington Ass'n of Realtors $^{27}$ the bar association brought an action to restrain certain practices of all licensed real estate brokers in the state. By unchallenged rulings of the trial court, the case was narrowed to only one defendant. The supreme court further limited the general application of the decision by emphasizing defects in only one particular document drafted by the defendant. The trial court had dismissed on the ground that there had been no compensation for the services. The supreme court reversed, directing that a decree of narrow scope be entered enjoining the specific activities theretofore engaged in by the defendant. 28 The basis of the decision was not a broad judicial power to define and regulate the unauthorized practice of law but the equitable power of courts to enjoin particular harmful activities. The court made no attempt to bring the activities within any definition of the practice of law nor to state a general rule concerning the unauthorized practice of law.29

25207 Minn. 642, 290 N.W. 795 (1940).

${ }^{26} \mathrm{Id}$. at $646,290 \mathrm{~N}$.W. at 797 . The court did not, however, accept the legislature's declaration that real estate brokers could charge for their legal services. Id. at 647,290 N.W. at 797.

2741 Wash. 2d 697, 251 P.2d 619 (1952).

28 "TThe decree] shall restrain the defendant from doing the specific kind of work of a legal nature evidenced by the preparation of the Voeller-Newman deed. We intend that the nature of this decree in this regard shall not necessarily define the terms of any decrees to be entered in any cases of this type which may arise in the future." Id. at 701, 251 P.2d at 622.

29 A concurring opinion argued for a broader decree: "I am of the opinion that respondent and other unlicensed persons should not be permitted to draw any deeds and/or any real-estate contracts for others. In other words, I believe that the court should exercise 
Companion cases decided by the Supreme Court of Alabama 30 illustrate judicial recognition of the distinction between the dominant legislative and judicial powers. The question in those cases was not one of legislative-judicial policy conflict, but rather one of whether the court should accept legislatively prescribed procedure. However, the results are significant as examples of judicial self-restraint in the area of unauthorized practice. In Birmingham Bar Ass'n v. Phillips \& Marsh, 31 the bar association brought an action to restrain the unauthorized practice of law by individuals, associations and corporations connected with the insurance business. The Alabama Supreme Court affirmed a judgment of non-suit because of a misjoinder of causes of action and of parties respondent. The court went further, however, and discussed why the statutory quo warranto proceeding was more appropriate than a summary proceeding based upon the inherent power of the courts. The court observed that several difficult questions of law were raised by the case and then continued:

Our recital of these inquiries is to give emphasis to our view that no summary procedure is to be pursued, but a procedure appropriate to this particular class of cases having the proper parties, and with all the incidents of due process of law. Such an appropriate remedy is expressly provided by our statutory action in the nature of quo warranto, a proceeding to which the State is a party. 32

On a rehearing, occasioned by the contrary result reached in Bessemer Bar Ass'n v. Fitzpatrick ${ }^{33}$-a case in which the defendant, not a licensed attorney, appeared in a representative capacity in the municipal court-the court adhered to its opinion. The per curiam decision overruling the application for rehearing distinguished the two cases. Referring to the Fitzpatrick case, the court said:

The power which thus exists in that court under those circumstances to adjudge and punish for such a contempt is not the same power which obtains in respect to one who does not so appear in court or otherwise participate in a proceeding in court representing another, and does not hold himself out as a lawyer, but who sets himself up in the pursuit of a profession having distinctive characteristics, and not thought by him to be within the purview of the legal profession. Such a person is not in contempt of any court. If he is engaged in a profession without complying

its inherent power to confine conveyancing and the preparation of contracts for others to those persons who are licensed to practice law in this state." 41 Wash. $2 \mathrm{~d}$ at 702, 251 P.2d at 622 .

30 Birmingham Bar Ass'n v. Phillips \& Marsh, 239 Ala. 650, 196 So. 725 (1940), rehearing denied, 239 Ala. 658, 196 So. 733 (1940); Bessemer Bar Ass'n v. Fitzpatrick, 239 Ala. 663, 196 So. 733 (1940).

31239 Ala. 650, 196 So. 725 (1940), rehearing denied, 239 Ala. 658, 196 So. 733 (1940).

32 Id. at 657,196 So. at 731 .

33239 Ala. 663, 196 So. 733 (1940). 
with the law so applicable, the duty breached is to the State and public, not to the courts nor to an individual. For the breach of such duty, the state should be the movant. The remedy is by quo warranto. 34

Although it is beyond the scope of this comment to attempt prediction of the substantive enactments which might be made by a legislature freed from the restrictions of a dominant judicial power, it might reasonably be hoped that legislatures would, in establishing requirements for particular areas of practice, make helpful distinctions in addition to that between attorneys and non-attorneys. The judicial attitude engendered by the assumption of a dominant judicial power would seem to have narrowed the courts' appreciation of the importance of non-legal skills. In a case involving practice before the state railway commission, ${ }^{35}$ the Nebraska Supreme Court may have overemphasized the importance of the legal skills required to argue before the commission and neglected to consider other special skills required. The court stated:

It is urged as a defense that to acquire and possess the knowledge necessary to have reasonable skill and efficiency in the handling of matters relating to the fixing and revision of transportation and service rates and charges of common carriers requires years of intensive and undivided study which few lawyers, if any, have undertaken. This is not a defense.... The fact that ... [the defendant] can qualify as an expert in a particular field will not permit his engaging lawfully in the profession of law without a license to do so.36

This disposition by the court illustrates the judicial attitude which results from the assumption of a broad and exclusive power to regulate the "practice of law." Just as the court has an inherent power to determine who should be licensed to appear in court in a representative capacity, the commission should have the power to determine what qualifications are suitable for its own "bar." 37 It may be that only specially trained lawyers should be permitted to practice. It may be that only particular legal skills are necessary. The commission itself is best able to ascertain the necessary qualifications. In areas in which administrative agencies have been delegated the power to determine requirements for their "bar," they have shown a concern-

${ }^{34}$ Birmingham Bar Ass'n v. Phillips \& Marsh, on application for rehearing, 239 Ala. $658,659,196$ So. 733 (1940).

${ }^{35}$ State ex rel. Johnson v. Childe, 139 Neb. 91, 295 N.W. 381 (1941).

$36 \mathrm{Id}$. at $95,295 \mathrm{~N}$.W. at $383-84$.

${ }^{37}$ See Gellhorn, supra note, 17; see also Waterman, Federal Administrative Bars: Admission and Disbarment, 3 U. CHI. L. Rev. 261, 262 (1936).

A rule of the Illinois Department of Finance establishing specific requirements for persons appearing before it in a representative capacity was held void in Chicago Bar Ass'n v. United Taxpayers of America, 312 Ill. App. 243, 38 N.E.2d 349 (1942). 
comparable to that of the courts-for establishing professional standards for advocates. 38

Since state legislatures and administrative agencies have not made forceful attempts to assert their dominant power, the assertion of the broad judicial power to regulate the practice of law is usually strong dictum only. It may be that control by the courts is satisfactory and that legislatures do not wish to assert different policies. However, it is possible that the assertion of power by the courts has caused legislatures and agencies to refrain from acting to implement what they consider appropriate policies. In 1934 the Senate of Massachusetts submitted to the Supreme Judicial Court questions concerning an unauthorized practice bill. 39 The bill contained an exception to the general prohibition which read "nothing herein shall prevent any individual from appearing before the industrial accident board in behalf of any injured person." 40 The court answered the questions in general terms:

[L]egislation forbidding the practice of law as therein described by corporations or associations or by individuals other than members of the bar of the Commonwealth is permissible, but ... legislation permitting the practice of law by such persons would not be constitutionally competent for the General Court.... Exceptions may be made to prohibitory provisions, but permission cannot thereby be conferred to practice law except subject to the judicial department of the government.41

The judicial assertion of inherent power thus blocked the effectuation of legislative policy which should have been dominant.

Texas presents another example of legislative abdication to judicial assertion of power. In 1947 the Texas legislature repealed a lengthy statute which had made unauthorized practice a misdemeanor. The emergency clause of the repealing act stated:

[T] he Act now being repealed has no practical value for the suppression of unauthorized practice of law, for the reason that the State Bar Act, subsequently enacted (Acts 1939, Forty-sixth Legislature, page 64) prohibits all persons not members of the State Bar from practicing law, and under the Constitution, the judicial department of the State government has power to define the practice of law and by civil proceedings protect the public from its practice by laymen and corporations, and the further fact that the presence of said Act on the books has created, and tends to create, much confusion....42

38 The Commissioner of Patents has promulgated a rule prohibiting advertising to solicit patent business. The rule was upheld as within the power delegated to the Commissioner by Congress in Evans v. Watson, 269 F.2d 775 (D.C. Cir. 1959), cert. denied, 361 U.S. 900 (1959). For a state court opinion distinguishing practice before the Patent Office and "practice of law" which the Patent Office could not authorize, see Chicago Bar Ass'n v. Kellogg, 338 IIl. App. 618, 88 N.E.2d 519 (1949).

39 Opinion of the Justices to the Senate, 289 Mass. 607, 194 N.E. 313 (1935).

$40 \mathrm{Id}$. at 609,194 N.E. at 315.

$41 \mathrm{Id}$. at $615-16,194$ N.E. at 318.

42 Texas Acts 1949 , ch. 301, §2, at 548. This clause is discussed in 5 BAyLOR L. REv. 71,72 (1952). 
The repealed act had excepted certain practices from its operation ${ }^{43}$ and in addition had contained a lengthy definition of the practice of law. All of this legislative declaration of policy was thought unnecessary because of the inherent power of the courts. It would appear to be preferable that the courts restrict their claim of dominant power to matters touching upon the dignity of the judicial process, and thereby encourage legislatures and administrative agencies to take a more active part in settling many of the difficult questions in other areas of unauthorized practice.

43 "NNothing] in this section [shall] prohibit any person or association of persons from pursuing as a vocation the business of adjusting insurance or freight rate claims; provided further that nothing in this Act shall prohibit any person or association of persons from appearing before any Board, Commission or Administrative body in connection with their vocation of adjusting Insurance or Freight Rate claims; ... . provided that nothing herein shall prevent Notaries Public from drawing conveyances for or without compensation." Texas Acts 1933, ch. 238, at 835, 836. 